\title{
"Determinants of consumer retention strategies for telecom service industry in Central India"
}

\begin{tabular}{|c|c|}
\hline AUTHORS & $\begin{array}{l}\text { Vinod Sharma } \text { https://orcid.org/0000-0002-0815-8502 } \\
\mathbb{R} \text { http://www.researcherid.com/rid/E-4283-2018 } \\
\text { Sunny Joseph } \mathbb{W} \text { https://orcid.org/0000-0003-3955-7693 } \\
\mathbb{R} \text { http://www.researcherid.com/rid/E-7182-2018 } \\
\text { Jeanne Poulose (D https://orcid.org/0000-0002-3370-4026 } \\
\mathbb{R} \text { http://www.researcherid.com/rid/E-4477-2018 }\end{array}$ \\
\hline ARTICLE INFO & $\begin{array}{l}\text { Vinod Sharma, Sunny Joseph and Jeanne Poulose (2018). Determinants of } \\
\text { consumer retention strategies for telecom service industry in Central India. } \\
\text { Problems and Perspectives in Management, 16(2), 306-320. } \\
\text { doi:10.21511/ppm.16(2).2018.28 }\end{array}$ \\
\hline DOI & http://dx.doi.org/10.21511/ppm.16(2).2018.28 \\
\hline RELEASED ON & Friday, 08 June 2018 \\
\hline RECEIVED ON & Monday, 05 March 2018 \\
\hline ACCEPTED ON & Wednesday, 23 May 2018 \\
\hline LICENSE & $\begin{array}{l}(\mathrm{coc}) \mathrm{EY} \text {-No } \\
\text { This work is licensed under a Creative Commons Attribution-NonCommercial } 4.0 \\
\text { International License }\end{array}$ \\
\hline JOURNAL & "Problems and Perspectives in Management" \\
\hline ISSN PRINT & $1727-7051$ \\
\hline ISSN ONLINE & $1810-5467$ \\
\hline PUBLISHER & LLC "Consulting Publishing Company "Business Perspectives" \\
\hline FOUNDER & LLC "Consulting Publishing Company "Business Perspectives" \\
\hline
\end{tabular}

NUMBER OF REFERENCES

84

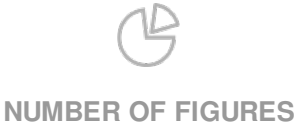

2

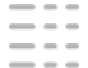

NUMBER OF TABLES

5

(C) The author(s) 2023. This publication is an open access article. 


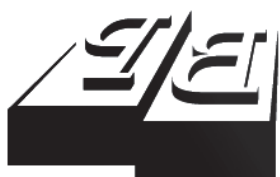

BUSINESS PERSPECTIVES

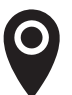

LLC "CPC "Business Perspectives" Hryhorii Skovoroda lane, 10, Sumy, 40022, Ukraine

www.businessperspectives.org

Received on: $5^{\text {th }}$ of March, 2018 Accepted on: $23^{\text {rd }}$ of May, 2018

(C) Vinod Sharma, Sunny Joseph, Jeanne Poulose, 2018

Vinod Sharma, Ph.D., Associate Professor of Marketing, Christ Institute of Management, Ghaziabad, India.

Sunny Joseph, Assistant Professor, CHRIST (Deemed to be University), Bangalore \& Vice Chairman, Christ Institute of Management, Ghaziabad, India.

Jeanne Poulose, M. Phil, Assistant Professor of HR, Christ Institute of Management, Ghaziabad, India.

\section{(ㄷ)(1) $(3$}

This is an Open Access article, distributed under the terms of the Creative Commons Attribution-NonCommercial 4.0 International license, which permits re-use, distribution, and reproduction, provided the materials aren't used for commercial purposes and the original work is properly cited.

\section{DETERMINANTS OF CONSUMER RETENTION STRATEGIES FOR TELECOM SERVICE INDUSTRY IN CENTRAL INDIA}

\begin{abstract}
The telecommunication industry has witnessed a tremendous growth in recent times in India. It has not only been limited to voice calls, but also integrated into every aspect of human life. This has resulted in the rapid rise of market players, offering innovative products and services. In this changing scenario, we have tried to design and check a model of various factors such as loyalty, satisfaction and switching barriers (customer relationship management, alternative attractiveness and switching cost) influencing consumer retention strategies in Indian telecom service industry.
\end{abstract}

A structured and undisguised questionnaire and a convenient sampling method have been used to collect the data from respondents from three most populous cities (Indore, Bhopal, and Ujjain) of Central India. Around 450 questionnaires were distributed, out of which 318 usable responses were received for final analysis. The instrument was checked for validity and reliability before the data was analyzed. The hypotheses were tested through Structure Equation Modelling (SEM) for direct effect, and Multiple Moderating Regression Analysis (MMRA) for moderating effect.

The results suggested that loyalty, satisfaction, switching barriers and customer relationship management are positively related and have a direct influence on consumer retention, but the relationship with alternative attractiveness has been found weak. Switching cost, as moderating variable, was found to be very effective and showed significant deviation in the relationship between independent and dependent variables.

\section{Keywords}

consumer retention strategies, consumer loyalty, consumer satisfaction, switching barriers, Structure Equation Modelling (SEM)

JEL Classification M31

\section{INTRODUCTION}

Today, if we took out telecommunication from our lives, the world around us would witness a systemic collapse. In the beginning, telecommunication was synonymous with voice calls, but in the present scenario with the technological advancements, it is involved in every aspect of human life, from entertainment to education, from navigating a car/flight/ship to navigating a space vehicle, from defence/security to health, from domestic businesses to global businesses, etc.

Telecom sector continues to scale up rapidly. International Telecommunication Union estimates that there are 7.9 billion mobile SIM connections globally, which is approximately equal to 100 percent of the global population (GSMA, 2017). An additional two billion subscription is predicted by 2020. In 2016, the penetration rate of unique mobile subscribers reached 4.8 billion, which was 65 percent of the world's population and it is predicted to reach 5.9 billion (73 percent) by 2020 (GSMA, 2017). Interestingly, prediction says that in the next period, it is expected to grow at a faster pace, contributing to 4.9 percent (USD 4.2 trillion) of world's GDP by 2020 . 
This market growth is mostly driven by developing nations like India and China, which account for 98 percent of mobile penetration. There were 1,206.71 million subscribers by September 2017, which accounts for 14 percent of mobile users (TRAI, 2017). Additionally, India is expected to add 27 percent (equals 206 million subscribers) of new subscribers by 2020 of the global markets. With the penetration rate of only $65 \%$, Indian telecom sector has considerable scope for growth (GSMA, 2017).

This growth has brought many positive changes in the industry, due to which it is now ranked as the second largest telecom sector in the world (GSMA, 2017). In order to outperform competitors and to explore the growing opportunities in this competitive market, companies are adapting innovating ways to reach the target audience to cater to their needs effectively and efficiently (Sharma \& Sonwalkar, 2016; Dharmakumar, 2013).

Reliance Jio, the youngest player in the Indian Telecom Sector's entry into the Indian market has brought along with it a lot of uncertainty in the industry. While it is clear that the objective is to outright dominate the market, it appears that it intends to do so by increasing its own subscriber base not just through new customers but largely by undercutting competition and poaching on their consumers (Gupta, 2018). All the major players are feeling the heat of the price war that has flared up in this industry. Vodafone India Q3 revenue fell by 23\% in 2017-2018 owing to these tariff wars (Sengupta, 2018). The two top players Bharti Airtel and Reliance Jio continue to lock horns and slashing rates is passé with freebies being the catch phrase for the two. Reliance in fact managed to add 16 million subscribers within the first month of its launch and the war continues with both players trying to nudge each other and the remaining players out of the race (Bhushan, 2017).

In this sense, it is imperative for firms not only to focus on acquiring new consumers, but also to devise plans to retain the existing ones, because studies confirm that retaining an existing consumer is five times cheaper than acquiring a new one (Sharma \& Sonwalkar, 2016; Kandampully, 2007; Shukla, 2004 cited by Sharma, Kapse, \& Sonwalkar, 2016). Therefore, this study undertakes an in-depth review and synthesis of current literature on consumer behavior/marketing to examine the emerging theories that underpin the idea of consumer retention strategies in a service industry such as telecom service industry.

Through an extensive literature review, it was found that there has been substantial number of studies in the past on consumer retention and several models have also been proposed (Alirez, 2011; Rahman, Haque, \& Ahmad, 2011; Molapo \& Mukwada, 2011), but the focus has been on studying the influence of consumer satisfaction, consumer loyalty and switching barriers on consumer retention. However, the authors through this study have proposed a model where a new component, Customer Relationship Management (CRM), has been included as a switching barrier to the components of Alternative Attractiveness and Switching Cost. Thus, consumer loyalty, customer satisfaction and switching barriers (including CRM, Alternative Attractiveness and Switching Cost) have been measured to see their influence on consumer retention. Even more significant is the fact that very few researches have been conducted in India and almost none specifically in Central India. The authors intend to rectify this through this study based exclusively on Central India. This study should also be of substance to researchers and practitioners, as they seek cutting-edge strategies, to outdo competitors.

\section{LITERATURE REVIEW}

Consumer retention signifies stretching out the ways and means to retain the consumers by satisfying them and meeting their needs. In this perspective, consumer retention is treated as the implication of strategy, which shows their posi- tive aspect of quality, services, performance and efficiency.

Different authors have given different views on consumer retention. According to the study conducted by Alirez (2011) in Iranian telecommunication sector, in order to create loyal consumers 
and to retain the existing ones, there was a need for implementing a successful system in the organization having a clear vision and commitment.

In order to retain consumers, Rahman, Haque, and Ahmad (2011) investigated the Malaysian mobile Telecom market where the choice criterion was in the hands of the service provider. It was revealed that brand image is not that important for the consumer but the price, service and quality of the network provided. In line with this thought, a few important strategies to retain the consumers of South African telecommunication operators were defined by Molapo and Mukwada (2011). Even they highlighted that the most effective strategy to retain the consumer is by providing them with quality of service, affordability of service and provision of consumer support services.

Moreover, many a time it happens that even dissatisfied consumers are found to be more loyal, and to retain them, five major factors should be taken into account such as switching cost, interpersonal relationship, the attractiveness of alternatives, service recovery and inertia (Yanamandram \& White, 2009). Considering all the arguments, the authors have used consumer loyalty, consumer satisfaction, switching barrier, customer relationship management, alternative attractiveness and switching cost as major independent variables for this study, which may help in increasing the consumer retention rate.

\subsection{Consumer loyalty}

In a study on customer loyalty the authors while defining it from a theoretical perspective, have referred to it as a collection of attitudes aligned with a series of purchase behaviors that systematically favor one entity over competing entities (Watson, Beck, Henderson, \& Robert, 2015). Research suggests that customer satisfaction and perceived value are significant predictors of customer loyalty (Ansari \& Riasi, 2016). A study on brand loyalty confirms that brand experience should be customized to support a customer's individualism and distinctiveness in order to stimulate brand loyalty (Ekinci, Whyatt, \& Nam, 2011). Studies suggest that customer loyalty is related to profitability (Hallowell, 1996). The results of a detailed study on the impact of private label brands on customer loyalty revealed that there is a significant relationship between the dollars spent by loyal customers and the department's profitability (Pepe, Abratt, \& Dion, 2011). An HBR article reveals that the cost of acquiring a new customer is 5 to 25 times more than retaining an existing customer (Gallo, 2014). The same article goes on to quote a study conducted by Bain \& Company that found that a $5 \%$ increase in customer retention produces more than $25 \%$ increase in profits. Past studies point that loyal customers spend more, provide free word of mouth publicity and visit more often (Compeau, 2011). What is to be seen in detail is the relation between customer satisfaction, customer loyalty and customer retention.

Consumer loyalty is a foremost indicator reflecting consumer satisfaction and if the consumer is satisfied one can say that there are fair chances for firms to retain them and therefore the authors of this article have also tried to find out the relationship between consumer loyalty and consumer retention. For this purpose, the very first hypothesis in the research was defined:

\section{H01: Consumer loyalty has a direct effect on con- sumer retention.}

\subsection{Consumer satisfaction}

Prior studies on consumer satisfaction and dissatisfaction highlight that satisfaction is the forebear to purchase intentions. Researchers have tried to explain many variances after observing consumer behavior. The study conducted by Churchill and Surprenant (1982) shows that consumer satisfaction is important as well as it is essential. Several studies have thus confirmed that when customers are satisfied there is a high chance of their being loyal (Siddiqi, 2011). In fact, study has revealed that switching barriers can be used to diminish consumer's switching decision even if satisfaction levels are low due to poor service offerings or performances (Sharma \& Panga, 2018; Han, Kim, \& Hyun, 2011).

Study reveals that consumers, while deciding whether to switch to other service provider, are often guided by their feelings of satisfaction/dissatisfaction. There is considerable debate and confusion about consumer satisfaction (Howard \& 
Sheth, 1969). On one hand, satisfaction is considered as an evaluation of a consumer's specific encounters with service providers/retailers and, on the other hand, it goes beyond a specific encounter to encompass all the encounters and experiences with the service provider and evaluation of the overall satisfaction level (Haridasan \& Venkatesh, 2013; Lam, Ahearne, Hu, \& Schillewaert, 2010; Cronin, Brady, \& Hult, 2000; Parasuraman, Zeithaml, \& Berry, 1994; Anderson \& Srinivasan, 2003; Balabanis, Reynolds, \& Simintiras, 2006; Burnham, Frels, \& Mahajan, 2003).

When we talk about the tools which help in increasing consumer retention (Lam, Ahearne, $\mathrm{Hu}$, \& Schillewaert, 2010; Sweeney \& Soutar, 2001), consumer satisfaction is one of the (Crosby \& Stephens, 1987; Crosby, Evans, \& Cowles, 1990). Satisfaction has been defined by Engel, Blackwell, and Miniard (1995), Inkumsah (2013) as "a post-consumption evaluation that a chosen alternative at least meets or exceeds expectations", while Ranaweera and Prabhu (2003) defined it as "an evaluation of an emotion, reflecting the degree to which the consumer believes the service provider evokes positive feelings". In light of this, the following hypothesis is proposed:

\section{H02: Consumer satisfaction has a direct effect on consumer retention.}

\subsection{Switching barriers}

Switching barriers are defined by Jones, David, and Sharon (2001, p. 261) as: "Any factor/element that makes it difficult or costly for consumers to change providers". Many authors use the term 'switching costs' and 'switching barriers' interchangeably (Alirez, 2011; Bansal \& Taylor, 1999; Bansal, Taylor, \& Jame, 2005; Ranaweera \& Prabhu, 2003) and many are confused in these terms (Sathish, Santhosh, Naveen, \& Jeevanantham, 2011; Balabanis, Reynolds, \& Simintiras, 2006; Colgate, Tong, Lee, \& Farley, 2007). Switching costs are onetime costs that are incurred by the consumer while shifting/switching from one provider to the other (Burnham, Frels, \& Mahajan, 2003). The same study goes on to cite Fornell (1992) who stated that a straight measure of switching barriers is complicated to obtain, as all costs associated with leaving a supplier in favor of another represent switching barriers. Other studies have pointed out that such switching barriers are important, as they help in customer retention while aiding organizations to deal with short-term fluctuations in quality that might otherwise result in consumer defection (Jones, Mothersbaugh, \& Beatty, 2000).

Referring to earlier researches, Han, Back, and Barrett (2009) have suggested that switching barriers include switching costs, relational investment and unattractive alternatives. Switching barriers are defined as the "consumer's consideration of the resources and opportunities needed to carry out the switching cost act (Seo \& Ranganathan, 2009; Ranaweera \& Prabhu, 2003). In today's competitive era, the success of the organization depends on the way switching barriers are evaluated and dealt with. Studies show that switching barriers are multidimensional (Sharma \& Panga, 2018; Antón, Camarero, \& Carrero, 2007; Colgate \& Lang, 2001; Han, 2009; Han, Back, \& Barrett, 2009; Jones, Mothersbaugh, \& Beatty, 2000; Jones, Reynolds, Mothersbaugh, \& Beatty, 2007; Vazquez-Carrasco \& Foxall, 2006) and it is found that nature and type of switching barriers vary from industry to industry (Fornell, 1992). Thus, as the switching barrier level increases, there are higher chances that consumer will not switch. So, to identify such relation, the following hypothesis was proposed:

H03: Switching barriers have a direct effect on consumer retention.

\section{Switching barrier 1: customer relationship management}

Effective marketing starts with Customer Relationship Management. This term emerged in the mid-1990s by vendor and practitioner community in Information Technology Sector. It thus describes technology-based customer solutions such as sales force automation (SFA). According to Sheth and Parvatiyar (1995), "Relationship Marketing and CRM are the two terms used interchangeably in academic community". However, in context of technology solutions, CRM is more commonly used and has been denoted as "information-enabled relationship marketing". Bell, Auh, and Smalley (2005), Ryals and Payne (2001), Zablah et al. (2004) suggested that CRM is "a phil- 
osophically-related offspring to relationship marketing which is, for the most part, neglected in the literature", and they conclude that "further exploration of CRM and its related phenomena is not only warranted but also desperately needed".

Keeping the above discussion in mind one can say that customer relationship management plays an important role in retaining the customer. Therefore, the authors of this article have also tried to analyze the relationship between the two constructs and for the same following hypothesis is being framed:

H04: Customer relationship management has a direct effect on consumer retention.

\section{Switching barrier 2: alternative attractiveness}

The second barrier in this study is the alternative attractiveness. Oliver (1997) defined one of the constructs as "consumers who are operating at the cognitive level are usually hypothesized and are more susceptible to switching, which is due to marketing overtures". Another construct underlying consumer switching barriers in Indian telecom sector is proposed for examination of alternatives attractiveness. According to Jones, Mothersbaugh, and Beatty (2000), alternative attractiveness refers to consumer "perceptions of the extent, to which viable competing alternatives are available in the marketplace". This construct is based on the consumer's perception of other available companies who could alternatively provide the product and/or service in question. As such, Kim, Yun, and Kim (2009), Breivik and Thorbjornsen (2008), Jones, Reynolds, Mothersbaugh, and Beatty (2007), Goode and Harris (2007), Holloway and Beatty (2003), Park, Feick, and Mothersbaugh (1994) defined it as not a measure of actual intensity of competition but rather the attractiveness of possible/acceptable alternatives as perceived by consumers.

As such, consumers who are not aware of the alternatives available to them are likely to be loyal (Patterson \& Smith, 2003). Thus, alternative attractiveness has a positive influence on consumer retention and for this end, the below-mentioned hypothesis was formed:

\section{H05: Alternative attractiveness has a direct effect on consumer retention.}

\section{Switching barrier 3: switching costs}

In strategy literature, the importance of switching costs has been validated. For instance, in understanding a first-mover product and the familiarity with the first brand in a product category, consumer investments will be the switching cost for him (Aaker, 2009).

\subsection{Typology of switching costs}

Burnham et al. (2003) developed a typology of switching costs based on the literature review and interviews with managers and focus groups. This typology consisted of eight distinct switching costs components including economic risk costs associated with the possible negative outcome from the new provider, evaluation costs involving the cost and benefit analysis undertaken before the actual switch, learning costs involving the investment in terms of time and resources to use the new product, set up costs involved in initiating the new services, benefit loss costs that is the benefits that the customer would have acquired on staying with the same brand, which he now has to forego. Additionally monetary loss costs incurred due to the one time financial outlay while switching coupled with the loss of personal relationships, while doing so is yet another important dimension. Finally, Burnham, Frels, and Mahajan (2003) refer to the loss to the consumer for breaking the relationship with the brand that he has been associated for long.

Based on the above view, the authors tried to study the moderating effect of switching cost on consumer loyalty, consumer satisfaction, customer relationship management and alternative attractiveness with respect to consumer retention. Therefore, the following hypotheses have been proposed:

H06: Switching cost will moderate the relationship between consumer loyalty and consumer retention.

H07: Switching cost will moderate the relationship between consumer satisfaction and consumer retention. 


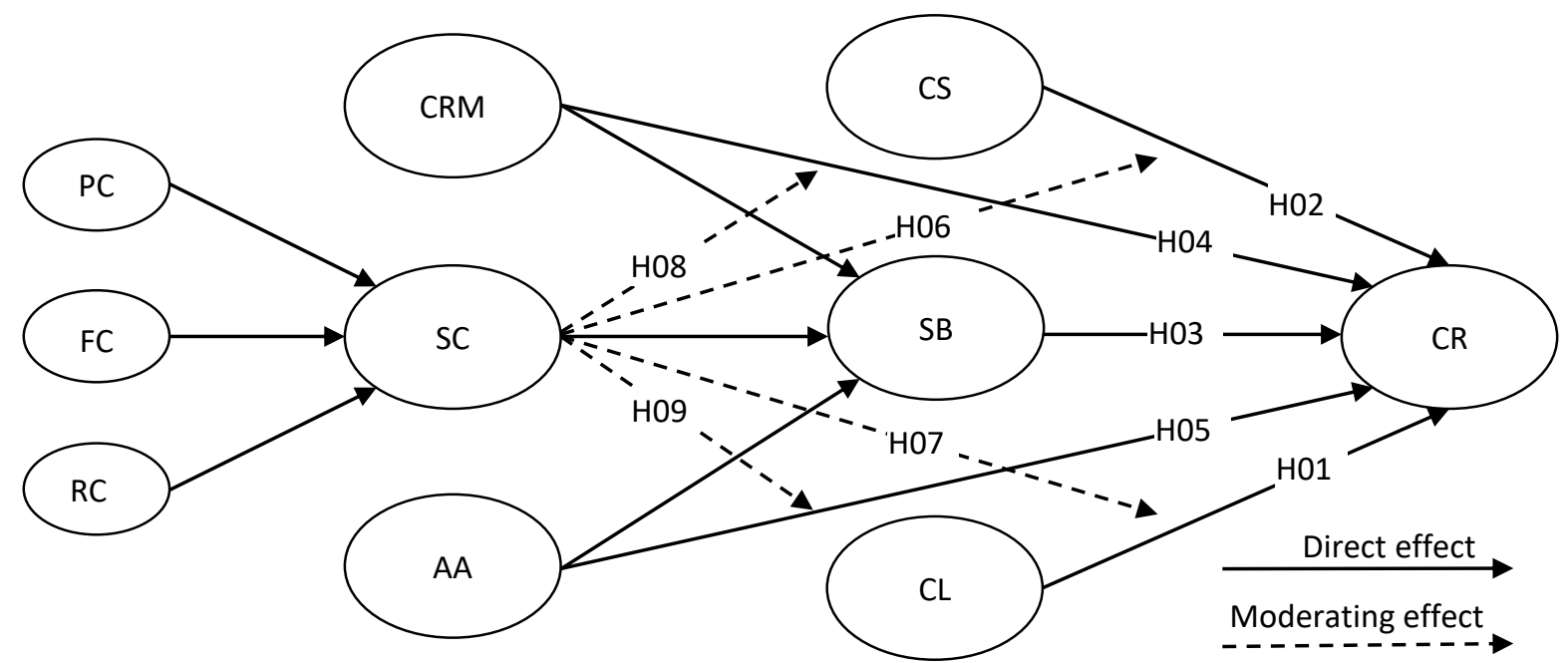

Note: CR: consumer retention; CL: consumer loyalty; CS: consumer satisfaction; SB: switching barrier; CRM: customer relationship management; AA: alternative attractiveness; SC: switching cost; PC: process cost; FC: financial cost; RC: relationship cost.

Figure 1. Proposed model of a determinant of consumer retention strategies

H08: Switching cost will moderate the relationship between customer relationship management and consumer retention.

H09: Switching cost will moderate the relationship between alternative attractiveness and consumer retention.

\section{RESEARCH METHODOLOGY}

In order to study the objectives developed in this study, a descriptive survey research design was found to be the most suitable for the research. Therefore, this research has followed the descriptive research design method. The data was collected from the post-paid mobile phone users of three major cities of Bhopal, Indore and Ujjain in Madhya Pradesh State through convenient sampling method. Data was collected manually and there was a qualifying question whether consumer was a post-paid consumer and he/she has been using the services for more than one year.

In this research, only post-paid telecom service users were selected for the research. Since previous studies confirm that the ratio between prepaid and post-paid subscriber base is $80: 20$, the average revenue per user is 4 times more in the case of post-paid users (TRAI, 2017). Thereby organizations give more importance to their post-paid subscribers and adopt various tools to retain the consumers and motivate them for more and more consumption.

\subsection{Measurement scale}

In this research, switching barriers and switching cost have been measured as latent variables. Switching barriers emerged with the composite effect of customer relationship management, alternative attractiveness and switching cost. And switching cost has emerged out of the composite effect of process cost, financial cost and relationship cost. The questions were developed by borrowing and modifying a few questions from previous studies (Antón, Camarero, \& Carrero, 2007; Burnham, Frels, \& Mahajan, 2003; Jones, Mothersbaugh, \& Beatty, Switching Barriers and Repurchase Intentions in Services, 2000; Patterson \& Smith, 2003) and the rest were created to suit the requirement of the study. Measuring the items, respondents were requested to mark their level of agreement on a 5-point Likert's scale (from strongly disagree to strongly agree). These scales were used to measure each of the individual constructs and their dimensions respectively.

\subsection{Pilot testing}

The pilot survey was carried out with a sample size of 65 telecom service consumers with a view to clarify questionnaire structure holistically and avoid any misinterpretation. 7 questions were 
Table 1. Reliability analysis

\begin{tabular}{|c|c|c|c|}
\hline No. & Scale & No. of items & Cronbach's alpha \\
\hline 1 & Consumer retention & 6 & 0.755 \\
\hline 2 & Consumer loyalty & 6 & 0.805 \\
\hline 3 & Consumer satisfaction & 6 & 0.726 \\
\hline 4 & Customer relationship management & 5 & 0.816 \\
\hline 5 & Alternative attractiveness & 6 & 0.752 \\
\hline 6 & Process cost & 7 & 0.701 \\
\hline 7 & Financial cost & 5 & 0.809 \\
\hline 8 & Relationship cost & 5 & 0.856 \\
\hline Cumulative & & 46 & 0.945 \\
\hline
\end{tabular}

found to be ambiguous and 4 were found to be irrelevant and repetitive in the first phase of the data collection. As at the time of data collection suggestions and comments were invited from the respondents to improve the scale, so those four irrelevant questions were removed, seven ambiguous questions were modified and five new questions were added.

\section{Sample size determination}

Zikmund (2004) defined the sample size of 250 to 500 to be appropriate to be used but the author also emphasized that the larger the sample size, the better the results are in SEM. Hair et al. (2010) and Chawla and Sondhi (2011) concluded that less than 5:1 ratio among the parameter is not appropriate for getting the precise results. Hence, the authors of this article distributed around 450 , out of which 318 usable responses were received for final analysis.

\section{Reliability and validity test}

Reliability can be defined as the degree to which an assessment tool produces stable and consistent results. It can take on values of 0 to 1.0 , inclusive.

Table 2. Convergent and discriminate validity
Literature suggests that a minimum value of Cronbach's alpha should be 0.7 for measuring the consistency of the scale (Hair, Black, Babin, \& Anderson, 2010; Zikmund, 2004; Nunnally \& Bernstein, 1994, p. 265; Robinson, Shaver, \& Wrightsman, 1991, pp. 12-13). As per Table 1, one can clearly say that the value of Cronbach's alpha is more than 0.7 in every scale which indicates a high level of internal consistency for each scale (Cronbach, 1951).

\subsection{Confirmatory factor analysis}

Convergent and discriminate validity were tested using confirmatory factor analysis in this paper on the eight dimensions identified earlier and they stand out to be significant. The convergent validity was confirmed through the values of Composite Reliability (CR > 0.7) (Bagozzi \& Yi, 1988) and Average Variance Explained (AVE > 0.5) (Hair, Black, Babin, \& Anderson, 2010) for each dimension. The items loaded on their respective factors and all the loadings were significant at $<0.01$ (Anderson \& Gerbing, 1988) showing good internal consistency. The results (see Table 2) confirm the same where the values of CR \& AVE were found to be well within the fit limit. To measure the discriminate validity, the value of AVE shall be greater than the values

\begin{tabular}{|c|c|c|c|c|c|}
\hline No & Dimensions & CR & AVE & MSV & ASV \\
\hline 1 & Consumer retention & 0.944 & 0.738 & 0.165 & 0.079 \\
\hline 2 & Consumer loyalty & 0.971 & 0.699 & 0.349 & 0.224 \\
\hline 3 & Consumer satisfaction & 0.949 & 0.683 & 0.298 & 0.212 \\
\hline 4 & Customer relationship management & 0.927 & 0.594 & 0.298 & 0.174 \\
\hline 5 & Alternative attractiveness & 0.945 & 0.652 & 0.545 & 0.237 \\
\hline 6 & Process cost & 0.928 & 0.584 & 0.545 & 0.283 \\
\hline 7 & Financial cost & 0.941 & 0.683 & 0.328 & 0.212 \\
\hline 8 & Relationship cost & 0.924 & 0.618 & 0.281 & 0.232 \\
\hline
\end{tabular}


Table 3. Index of the model fit

\begin{tabular}{c|c|c|c|c|c|c|c|c}
\hline CMIN & DF & p-value & CMIN/DF & GFI & PCFI & CFI & RMSEA & PCLOSE \\
\hline 2363.625 & 893 & 0.00 & 2.647 & 0.899 & 0.812 & 0.901 & 0.041 & 0.000 \\
\hline
\end{tabular}

of maximum shared variance (MSV) and average shared variance (ASV), respectively (Gefen, Starub, \& Boudreau, 2000; Hair, Black, Babin, \& Anderson, 2010). The test results confirmed the same (see Table 2) for each dimension.

\subsection{Data analysis and hypothesis testing}

Ultimately 318 responses were finalized for the statistical analysis, out of which $201(63.2 \%)$ were male and 117 (36.8\%) were female consumers. Majority of people who responded were graduates, $203(63.8 \%)$ followed by postgraduates who accounted for 67 (21.1\%), people having advanced degree accounted for 44 (13.8\%) and below graduates were just 4 (1.3\%). $27 \%$ respondents earned between 4.5 to $6 \mathrm{Lac}$ rupee per year, $23 \%$ respondents earned between 1.5 to 3 Lac per year, $18.3 \%$ respondents earned between 3 to $4.5 \mathrm{Lac}, 16 \%$ respondents earned below 1.5 Lac and $15.7 \%$ of the respondents earned above $6 \mathrm{Lac}$ per year.

\section{Direct effect assessment of structural model and hypotheses testing}

The SEM was used to find out the structural relationship of the full proposed model in the study. First, it was measured whether the estimated coefficients were large enough or close to one as the accepted threshold value was 0.95 and it was found that the offending variance in this study was statistically suitable. Thus, the fit of indicator to each construction could be further examined.

The structural model appears to be well within the acceptable limit of the goodness of fit (see Table 3). All the indicators of the model are within the threshold of the structural model.

The results indicate that the CMIN/DF value is 2.647 , which is acceptable for default model (measurement model). The Comparative Fit Index (CFI) compares the existing model fit with a null model which assumes the indicator variables (and hence also the latent variables) in the model are uncorrelated (the independence model). CFI varies from 0 to 1 (Gefen, Starub, \& Boudreau, 2000). CFI close to 1 indicates a very good fit. CFI value in the test result is 0.901 which is close to 1 .

After that the authors took parsimony adjusted measures index, there was no commonly cut off value for accepting this value, but greater than .60 was considered as a good fit and here it was found 0.812 , which indicated quite a good fit of the model. Root Mean Square Error of Approximation is a popular measure of fit. RMSEA value less than or equal to 0.06 is considered as a good fit (Paswan, 2009) as cited by Sharma, Poulose, Mohanta, and Antony (2018). However, a RMSEA value of 0.041 was obtained and hence it was considered to be a good fit.

It can be observed from the Table 3, that there is a strong variability caused by independent

Table 4. Hypotheses testing results

\begin{tabular}{c:l|c|c|c}
\hline S. No. & \multicolumn{1}{|c|}{ Hypotheses } & Effect & $p$-value & Results \\
\hline $\mathrm{H}_{01}$ & Consumer loyalty $\rightarrow$ consumer retention & 0.347 & 0.000 & Supported \\
\hdashline $\mathrm{H}_{02}$ & Consumer satisfaction $\rightarrow$ consumer retention & 0.276 & 0.000 & Supported \\
\hdashline $\mathrm{H}_{03}$ & Switching barrier $\rightarrow$ consumer retention & 0.119 & 0.034 & Supported \\
$\mathrm{H}_{04}$ & Customer relationship management $\rightarrow$ consumer retention & 0.379 & 0.000 & Supported \\
\hdashline $\mathrm{H}_{05}$ & Alternative attractiveness $\rightarrow$ consumer retention & 0.040 & 0.483 & Not-supported \\
\hline
\end{tabular}


Table 5. Moderating effect

\begin{tabular}{c|c|c|c|c|c|c}
\hline No. & Hypotheses & $\begin{array}{c}\text { Beta } \\
\text { coefficient }\end{array}$ & p-value & $\begin{array}{c}\text { Change in beta } \\
\text { Coefficient }\end{array}$ & p-value & Result \\
\hline 1 & H06 & 0.347 & 0.000 & 0.151 & Fully mediated \\
and significant
\end{tabular}

variables (consumer loyalty, consumer satisfaction, switching barrier and customer relationship management) on dependent variables (consumer retention). Results of $H_{01}, H_{02}, H_{03}$ and $H_{04}$ were found significant $(0.000)$, which is less than 0.05 , and have a direct effect on consumer retention. Betas coefficient predicted strong changes in the consumer retention by consumer loyalty, consumer satisfaction, switching barrier and customer relationship management. Beta coefficient value of consumer loyalty was 0.347 , which showed around $35 \%$ positive variability in consumer retention (dependent variable) caused. Similarly, all other independent variables such as consumer satisfaction (0.276), switching barrier (0.119) and customer relationship management (0.379) reported a high level of variability in respective consumer retention. However, alternative attractiveness $\left(H_{05}\right)$ had a very weak relationship $(0.040)$ with consumer retention and the model was not found significant.

\section{Moderating effect}

A moderated analysis has been used to determine whether the relationship between consumer retention and other independent variables is moderated by the switching cost. To analyze the same, the standard method of determining whether a moderating effect exists has been used, which entails the addition of an (linear) interaction term in multiple regression model, which is also known as Moderated Multiple Regression Analysis (MMRA). This method is considered to be a simple and very reliable method to analyze the interaction behavior of any variable.
The results indicate that the latent interactions of switching cost and consumer loyalty (SC*Loy) show positive path coefficients for consumer retention $(\beta=0.151 ; p=0.000)$. Therefore, one can say that the interaction effect of switching cost fully moderated the relationship of consumer loyalty and consumer retention. Thus, $H_{06}$ is fully moderated and significant. This finding is in line with the finding by Chebat, Davidow, and Borges (2010). Similarly, the result of thelatentinteractions of switching cost and consumer satisfaction (SC*Sat) shows positive path coefficients for consumer retention $(\beta=0.181 ; p=0.000)$. This confirms, as expected and hypothesized, that switching costs moderate the relationship between consumer satisfaction and consumer retention. Therefore, $H_{07}$ is fully moderated and significant. This result is consistent with Mohsin, Ahmad, and Ahmed (2012). Furthermore, the latent interactions of switching cost and customer relationship management (CRM) $\left(\mathrm{SC}^{\star} \mathrm{CRM}\right)$ show a negative path coefficients for consumer retention $(\beta=-0.114 ; p=0.001)$. This confirms, as expected and hypothesized, that switching costs moderates the relationship between CRM and consumer retention. Therefore, $H_{08}$ is fully moderated and significant. This result is again consistent with Mohsin, Ahmad, and Ahmed (2012). Finally, the latent interactions of switching cost and alternative attractiveness ( $\mathrm{AA})\left(\mathrm{SC}^{\star} \mathrm{AA}\right)$ show a positive and significant path coefficients for consumer retention $(\beta=0.341 ; p=0.041)$. This confirms, as expected and hypothesized, that switching costs moderate the relationship between AA and consumer retention. Therefore, $H_{09}$ is fully moderated and significant. This result is consistent with Mohsin, Ahmad, and Ahmed (2012), Aydin, Özer, and Arasil (2005). 


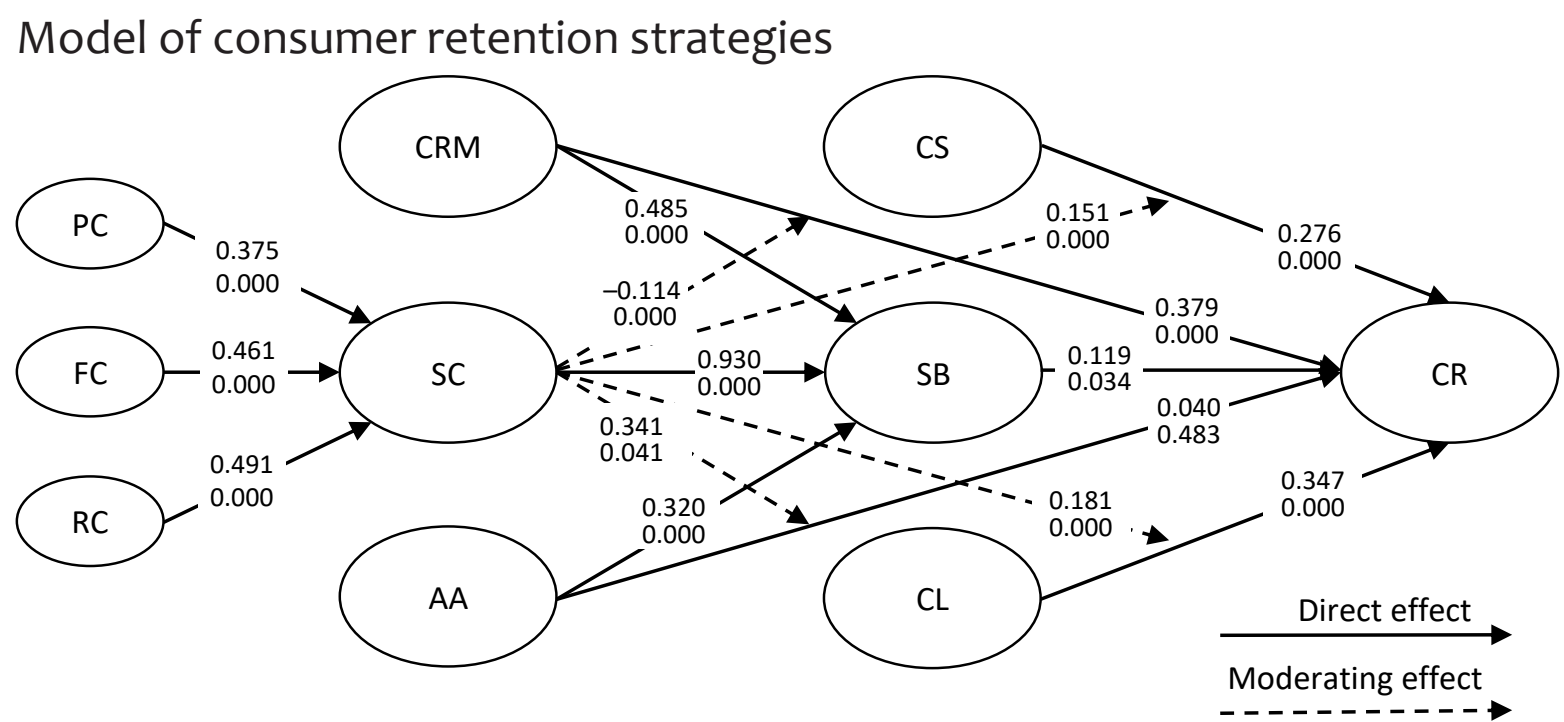

Note: CR: consumer retention; CL: consumer loyalty; CS: consumer satisfaction; SB: switching barrier; CRM: customer relationship management; AA: alternative attractiveness; SC: switching cost; PC: process cost; FC: financial cost; RC: relationship cost. $\chi 2=2363.625(\rho=0.000) ; \mathrm{df}=893,(\chi 2 / \mathrm{df})=2.647, \mathrm{RMSEA}=0.041(\mathrm{PCLOSE}=0.000) ; \mathrm{GFI}=0.899 ; \mathrm{CFI}=0.901$, PCFI $=0.812$

Figure 2. Structured model of a determinant of consumer retention strategies

\section{CONCLUSION}

Consumer loyalty $\rightarrow$ Consumer Retention $\left(H_{01}\right)$

The result supports $H_{01}$, which posits that consumer loyalty has a direct and positive influence on consumer retention. This is in line with past findings in the literature (Molapo \& Mukwada, 2011; Ali, Ali, Rehman, Yilmaz, \& Safwan, 2010; Martin, 2008; Reibstein, 2002), in that greater consumer loyalty leads to higher consumer retention. This implies that greater consumer loyalty acts as a switching barrier by making it difficult for the consumer to leave thus increasing consumer retention.

\section{Consumer satisfaction $\rightarrow$ Consumer retention $\left(\mathrm{H}_{02}\right)$}

The result supports $H_{02}$, which validates that consumer satisfaction has a direct and positive influence on consumer retention. This is in line with past findings in the literature (Inkumsah, 2013; Shukla, 2004; Szymanski \& Henard, 2001), in that greater consumer satisfaction leads to higher consumer retention.

It has also been identified by many researchers in different industries before that satisfied consumers tend to have a higher level of service usage and stronger repurchase intentions compared with those who are less satisfied. This finding also reinforced the applicability of this relationship in telecom service sector.

\section{Switching barriers $\rightarrow$ Consumer retention $\left(H_{03}\right)$}

$H_{03}$ suggests that the cumulative results of switching barriers have shown that there is a significant and positive influence on consumer retention. Furthermore, observing the beta value for checking up a load of switching barrier, it is found that with the value of 0.307 it has a very positive influence on consumer retention. This is in line with past findings in the literature (Antón, Camarero, \& Carrero, 2007; Colgate \& Lang, 2001; Han, 2009; Han, Back, \& Barrett, 2009), in that the higher the switching barrier, the higher the chances of retaining consumers. 


\section{Customer relationship management $\rightarrow$ Consumer retention $\left(H_{04}\right)$}

Hypothesis results have shown a direct positive relationship between customer relationship management and consumer retention (standardized coefficient $=0.379 ; p<0.05$ ). In case of Indian telecom service sector, CRM plays a pivotal role in retaining the consumers. This is in line with past findings in the literature (Bell, Auh, \& Smalley, 2005; Ryals \& Payne, 2001; Zablah, Bellenger, \& Johnston, 2004), where authors have found that good customer service leads to higher consumer retention.

\section{Alternative attractiveness $\rightarrow$ Consumer retention $\left(H_{05}\right)$}

Yet another vital component of switching barrier identified in the literature review is alternative attractiveness. As per the finding, in the Indian telecom market, this construct is not that important factor, which individually drives the consumer to switch. This is evidenced by the negligible and insignificant influence (standardized coefficient $=0.040$ ) of the attractive alternatives perception on consumer retention. This implies that there is no influence of the number of alternatives on the consumer retention. Surprisingly, this finding quite contrasts to the results of previous research Kim, Yun, and Kim (2009); Breivik and Thorbjornsen (2008) \& Jones, Reynolds, Mothersbaugh, and Beatty (2007) that commitment of individual will increase when there are no alternatives available for the services they use and which give them maximum satisfaction. This means lack of availability of alternatives in the marketplace will decrease the probability of switching and the likelihood of remaining with the current service provider will increase and hence organizations will get the competitive edge.

\section{Switching cost ${ }^{*}$ loyalty $\rightarrow$ Consumer retention $\left(H_{06}\right)$}

This study found moderating effects of switching costs on consumer loyalty. There was a strong variation in the coefficient value found in the result. There was a positive moderating effect of switching costs on loyalty and consumer retention. Thus, it can be concluded that if switching costs are high then the consumer will prefer to be loyal rather than getting into the hassle of incurring an unnecessary and unavoidable cost.

\section{Switching cost ${ }^{*}$ satisfaction $\rightarrow$ Consumer retention $\left(H_{07}\right)$}

Switching costs also moderate the relationship between consumer satisfaction and consumer retention. The result shows that switching costs act as assurance in strengthening the relationship between satisfaction and consumer retention. This implies that when the costs of switching are seen to be high, even those customers who are low on satisfaction will hesitate to switch. This low consumer satisfaction will not translate to lost consumer because of the high switching costs. Thus, one can say that in telecom services, consumers will not switch if they realize that the switching cost is higher and, hence, even less satisfied consumer would prefer to stay with the organization.

\section{Switching cost ${ }^{*}$ customer relationship management $\rightarrow$ Consumer retention $\left(H_{08}\right)$}

As observed in literature as well as in the test results, there is a direct and positive effect of CRM on consumer retention, but at the same time it was observed that the interaction of switching cost strongly moderates the relationship between them. This means that even though the switching costs moderate, but if the organization provides the promised services and nourishes the healthy relations, then the organization won't lose the consumer at any point in time. Hence, CRM is found to be the most important switching barrier in retaining consumer. 


\section{Switching cost ${ }^{*}$ alternative attractiveness $\rightarrow$ Consumer retention $\left(H_{00}\right)$}

$H_{09}$ shows the moderating role of perceived switching costs in the association with the alternative attractiveness and consumer retention and the result was found to be significant. This study found negative moderating effects of switching costs on alternative attractiveness and consumer retention.

\section{Managerial contributions}

The outcome of this research has also provided managerial implication for the Indian Telecom industry. In line with past studies on the Indian telecom sector, the present study has also highlighted the importance of satisfaction, loyalty and switching barriers in retaining consumers in the Indian telecom industry.

This study suggests that Indian telecom service providers should strategically nurture the perceptions of retaining the consumers. As it is being observed in the previous researches, acquiring a new consumer is five times costlier than retaining the existing one. It means that service providers should focus more on providing quality services, which will help them in creating a better word of mouth and a satisfied and loyal consumer base. This strategic move of the organization will offer a competitive advantage/edge, which will further enhance the profitability and growth of an organization.

Summing up it can be said that organizations can get consumers to stay either by raising exit barriers like switching costs and/or by motivating them to stay by offering better service, ensuring consumer satisfaction and rewarding customer loyalty. Application of such positive strategies and their outcomes against the negative strategies of consumer retention needs to be studied in detail.

\section{Limitation and suggestions}

There are a few limitations of this study. First, this study has investigated the three major components of consumer retention in Indian telecom sector; it has not focused on examining the importance placed on each parameter by consumers. For example, the effect of each dimension on consumer retention remains to be tested. Second, switching cost in this research has been considered as a moderating variable whereas previous studies also found that there was a direct influence of switching cost with consumer retention. The third limitation of the study is that the sample was collected from central India (Madhya Pradesh), whereas this research can be conducted at the national level or at zonal level. This can help in generalizing the results obtained.

The scope of this study is confined to defining only three components of consumer retention in Indian telecom sector. However, this study can also define several other components, which affect the consumer retention. Further, this study can also help in studying the role of switching barriers as a consumer retention tool. By considering the different aspects of Indian telecom service industry, a comparative study will help the service providers to make a strategic move as to how to retain consumers.

\section{ACKNOWLEDGEMENT}

This research is partially funded by the Christ Institute of Management, Ghaziabad (CHRIST, Deemed to be University Trust, Bangalore). 


\section{REFERENCES}

1. Aaker, D. A. (2009). Strategic Market Management: Wiley-India. Aarts, Henk and Dijksterhuis, Ap. (2000). Habits as Knowledge Structures: Automaticity in GoalDirected Behavior. Journal of Personality and Social Psychology, 78(1), 53-63.

2. Ali, F. J., Ali, I., Rehman, K. U., Yilmaz, A. K., \& Safwan, N. (2010). Determinants of consumer retention in cellular industry of Pakistan. African Journal of Business Management, 4(12), 2402-2408. Retrieved from http:// www.academicjournals.org/ article/article1380787868_Ali\%20 et $\% 20$ al.pdf

3. Alirez, F. (2011). How Quality, Value Image, and Satisfaction Create Loyalty at an Iran Telecom. International Journal of Business and Management, 6(8), 271279. Retrieved from http://www. ccsenet.org/journal/index.php/ ijbm/article/view/8561

4. Anderson, J. C., \& Gerbing, W. D. (1988). Structural Equation Modeling in Practice: A Review and Recommended Two-Step Approach. Psychological Bulletin, 103, 411-423.

5. Anderson, R. E., \& Srinivasan, S. S. (2003). E-Satisfaction and E-Loyalty: A Contingency Framework. Psychology and Marketing, 20(2), 123-138. https:// doi.org/10.1002/mar.10063

6. Ansari, A., \& Riasi, A. (2016). Modelling and evaluating customer loyalty using neural networks: Evidence from startup insurance companies. Future Business Journal, 2(1), 15-30.

7. Antón, C., Camarero, C., \& Carrero, M. (2007). Analysing Firms' Failures as Determinants of Consumer Switching Intentions the Effect of Moderating Factors. European Journal of Marketing, 41(1-2), 135-158.

8. Aydin, S., Özer, G., \& Arasil, Ö. (2005). Customer Loyalty and the Effect of Switching Costs as a Moderator Variable. A Case in the Turkish Mobile Phone
Market. Marketing Intelligence and Planning, 23(1), 89-103.

9. Bagozzi, P. R., \& Yi, Y. (1988). On the evaluation of structural equation models. Journal of the Academy of Marketing Science, 16(1), 74-94. Retrived from http://www.scirp.org/ (S(351jmbntvnsjtlaadkposzje))/ reference/ReferencesPapers. aspx?ReferenceID=1605812

10. Balabanis, G., Reynolds, N., \& Simintiras, A. (2006). Bases of E-Store Loyalty: Perceived Switching Barriers and Satisfaction. Journal of Business Research, 59(2), 214-224.

11. Bansal, H. S., \& Taylor, S. F. (1999). The Service Provider Switching Model (SPSM): A Model of Consumer Switching Behavior in the Services Industry. Journal of Service Research, 2(2), 200-218.

12. Bansal, H. S., Taylor, S. F., \& Jame, S. Y. (2005). Migrating to New Service Providers: Toward a Unifying Framework of Consumers' Switching Behaviors. Journal of the Academy of Marketing Science, 33(1), 96-115.

13. Bell, S. J., Auh, S., \& Smalley, K. (2005). Customer Relationship Dynamics: Service Quality and Customer Loyalty in the Context of Varying Levels of Customer Expertise and Switching Costs. Journal of the Academy of Marketing Science, 32(2).

14. Bhushan, K. (2017, October 13). It's a war between Bharti Airtel and Reliance Jio. Retrieved May 19, 2018 from hindustan times. com https://www.hindustantimes. com/tech/it-s-war-between-bhartiairtel-and-reliance-jio/storyEl3iIs4ziufgIDduF51hJJ.html

15. Breivik, E., \& Thorbjornsen, H. (2008). Consumer Brand Relationships: An Investigation of Two Alternative Models. Journal of the Academy of Marketing Science, 36(4), 443-472.

16. Burnham, A. T., Frels, J. K., \& Mahajan, V. (2003). Consumer Switching Costs: A Typology,
Antecedents, and Consequences. Journal of Academy of Marketing Science, 31(2), 109-126.

17. Chawla, D., \& Sondhi, N. (2011). Research Methodology: Concepts and Cases (Vol. 1). New Delhi: Vikas Publishing House Pvt. Ltd.

18. Chebat, J.-C., Davidow, M., \& Borges, A. (2010). More on the Role of Switching Costs in Service Markets: A Research Note. Journal of Business Research, 64(8), 823-829.

19. Churchill, G. A., \& Surprenant, C. (1982). An Investigation into the Determinants of Customer Satisfaction. Journal of Marketing Research, 491-504.

20. Colgate, M. R., \& Lang, B. (2001) Switching Barriers in Consumer Markets: An Investigation of the Financial Services Industry. Journal of Consumer Marketing, 18(4), 332-347.

21. Colgate, M., Tong, V. T.-U., Lee, C. K.-C., \& Farley, J. U. (2007). Back from the Brink: Why Customers Stay. Journal of Service Research, 9(3), 211-228.

22. Compeau, M. (2011, October 3). None ways to build customer loyalty. Forbes.

23. Cronbach, L. J. (1951). Coefficient Alpha and the Internal Structure of Tests. Psychometrika, 31, 93-96.

24. Cronin, J. J., Brady, M. K., \& Hult, G. M. (2000). Assessing the Effects of Quality, Value, and Customer Satisfaction on Consumer Behavioral Intentions in Service Environments. Journal of Retailing, 76(2), 193-218.

25. Crosby, L. A., \& Stephens, N. (1987). Effects of Relationship Marketing on Satisfaction, Retention, and Prices in the Life Insurance Industry. Journal of Marketing Research, 24(4), 404411.

26. Crosby, L. A., Evans, K. R., \& Cowles, D. (1990). Relationship Quality in Services Selling: An Interpersonal Influence Perspective. Journal of Marketing, 54(3), 68-81. 
27. Dharmakumar, R. (2013, January 17). India and Technology Multinationals - Part 1. Retrieved from http://forbesindia.com/blog/ author/rohin-dharmakumar/ page/2/ (accessed on January 25, 2015).

28. Ekinci, Y., Whyatt, G., \& Nam, J. (2011). Brand equity, brand loyalty and customer satisfaction. Annals of Tourism Research.

29. Engel, J., Blackwell, R., \& Miniard, P. (1995). Consumer Behaviour. The Dryden Press, USA.

30. Fornell, C. (1992). A national satisfaction barometer: the Swedish experience. Journal of Marketing, 56(1), 6-21.

31. Gallo, A. (2014, October 29). The value of keeping the right cusotmers. Harvard Business Review.

32. Gefen, D., Starub, D., \& Boudreau, M. (2000). Structural Equation Modeling and Regression: Guidelines for Research Practice. Communications of AIS, 7(7), 1-78.

33. Goode, M. M., \& Harris, L. C. (2007). Online Behavioural Intentions: An Empirical Investigation of Antecedents and Moderators. European Journal of Marketing, 41(5-6), 512-536.

34. GSMA, I. (2017). The mobile economy 2017. London: GSMA.

35. Gupta, S. (2018, January 30). Reliance Jio price wars have made telecom valuations untenable: analysts. Retrieved from www.livemint.com: https:// www.livemint.com/Industry/ hkeebeQW9LIIuSzsL8ijuO/ Reliance-Jio-price-wars-havemade-telecom-valuations-untenab. html (accessed on May19, 2018).

36. Hair, J. F., Black, W. C., Babin, B. J., \& Anderson, R. E. (2010). Multivariate Data Analysis: A Global Perspective (7th ed.). New Jersey: Pearson Prentice Hall.

37. Hair, J., Black, C. W., Babin, J. B., \& Anderson, E. R. (2010). Multivariate data analysis (7th ed.). Upper Saddle River, New Jersey (NJ): Pearson Education International.
38. Hallowell, R. (1996). The relationships of customer satisfaction, customer loyalty and profitability: an empirical study. International Journal of Service Industry Management, 7(4), 27-42.

39. Han, H. (2009). Emotions and switching barriers in full-service restaurants. Germany Saarbrucken: VDM Publishing House.

40. Han, H., Back, K., \& Barrett, B. (2009). Influencing factors on restaurant customers' revisit intention: the roles of emotions and switching barriers. International Journal of Hospitality Management, 28, 563-572.

41. Han, H., Kim, W., \& Hyun, S. S. (2011). Switching intention model development. International Journal of Hospitality Management.

42. Haridasan, V., \& Venkatesh, S. (2013). Service Marketing. International Journal of Business Research and Management (IJBRM), 2(3), 111-126.

43. Holloway, B. B., \& Beatty, S. E. (2003). Service Failure in Online Retailing: A Recovery Opportunity. Journal of Service Research, 6(1), 92-105.

44. Howard, J. A., \& Sheth, J. N. (1969). The Theory of Buyer Behavior. New York: John Wiley \& Sons, Inc.

45. Inkumsah, A. W. (2013). Factors That Impacted Customer Retention of Banks. A Study of Recently Acquired Banks in the UPSA Area of Madina, Accra (Specifically Access Bank). Journal of Marketing and Consumer Research, 1, 88-103.

46. Jones, A. M., Mothersbaugh, L. D., \& Beatty, E. S. (2000). Switching Barriers and Repurchase Intentions in services. Journal of Retailing, 76, 259-274.

47. Jones, M. A., David, L., \& Sharon, E. B. (2001). Switching Barriers and Repurchase Intentions in Services. Journal of Retailing, 76(2), 259-274.

48. Jones, M. A., Reynolds, K. E., Mothersbaugh, D. L., \& Beatty, S. E. (2007). The Positive and Negative Effects of Switching Costs on Relational Outcomes. Journal of Service Research, 9(4), 335-355.

49. Kandampully, J. A.-H. (2007). Do hoteliers need to manage image to retain loyal customers? International Journal of Contemporary Hospitality Management, 19(6), 435-443.

50. Kim, K., Yun, D., \& Kim, D. (2009). Expectations measurements in mobile data service: a case study. International Journal of Mobile Communications, 7(1), 91-116.

51. Lam, S. K., Ahearne, M., Hu, Y., \& Schillewaert, N. (2010). Resistance To Brand Switching When A Radically New Brand Is Introduced: A Social Identity Theory Perspective. Journal of Marketing (AMA), 1-58.

52. Martin, B. (2008). Determining the Impact of Internet Channel Use on a Customer's Lifetime. Journal of Interactive Marketing, 22(3), 2-22.

53. Mohsin, A., Ahmad, R., \& Ahmed, A. (2012). Determinants of customer switching behavior in banking sector. Studies in Business and Economics, 20-34.

54. Molapo, E. M., \& Mukwada, G. (2011). The Impact of Customer Retention Strategies in the South African Cellular Industry: The Case of the Eastern Free State. International Journal of Business Humanities and Technology, 1(2), 52-60.

55. Nunnally, J. C., \& Bernstein, I. H. (1994). Psychometric Theory. New York: McGraw-Hill.

56. Oliver, R. L. (1997). Satisfaction: A Behavioral Perspective on the Consumer. Irwin McGraw-Hill.

57. Parasuraman, A., Zeithaml, V. A., \& Berry, L. L. (1994). Reassessment of Expectations as a Comparison Standard in Measuring Service Quality: Implications for Further Research. Journal of Marketing, 58(1), 111-124.

58. Park, W. C., Feick, A., \& Mothersbaugh, D. L. (1994). Consumer Knowledge Assessment. Journal of Consumer Research, 21(1), 71-82.

59. Paswan, A. (2009). Confirmatory Factor Analysis and Structural Equations Modeling. An Introduction. North Texas, USA: Department of Marketing and Logistics, COB, University of North Texas, USA. 
60. Patterson, P. G., \& Smith, T. (2003). A Cross-Cultural Study of Switching Barriers and Propensity to Stay with Service Providers. Journal of Retailing, 79(2), 107-120.

61. Pepe, M. S., Abratt, R., \& Dion, P. (2011). The impact of private label brands on customer loyalty and product category profitability. Journal of Product and Brand Management, 20(1), 27-36.

62. Rahman, S., Haque, A., \& Ahmad, S. (2011). Choice Criteria for Mobile Telecom Operator: Empirical Investigation among Malaysian Customers. International Management review, 7(1), 50-57.

63. Ranaweera, C., \& Prabhu, J. (2003). The Influence of Satisfaction, Trust and Switching Barriers on Customer Retention in a Continuous Purchasing Setting. International Journal of Service Industry Management, 14(3/4), 374-395.

64. Reibstein, D. J. (2002). What Attracts Customers to Online Stores, and What Keeps Them Coming Back? Journal of the Academy of Marketing Science, 30(4), 465-473.

65. Robinson, J. P., Shaver, P. R., \& Wrightsman, L. S. (1991). Criteria for Selection and Evaluation. In John P. Robinson, Phillip R. Shaver and Lawrence $S$. Wrightsman (Eds.), Measures of Personality and Social Psychological Attitudes (vol. 1, pp. 1-16). San Diego, Calif: Academic Press.

66. Ryals, L., \& Payne, A. F. (2001, March). Customer Relationship Management in Financial Services: Towards Information-Enabled Relationship Marketing. Journal of Strategic Marketing, 9, 1-25.

67. Sathish, M., Santhosh, K. K., Naveen, K., \& Jeevanantham, V. (2011). A Study on Consumer Switching Behaviour in Cellular Service Provider: A Study with reference to Chennai. Far East Journal of Psychology and Business, 2(2), 71-81.

68. Sengupta, D. (2018, 0201$)$. Vodafone India Q3 revenue drops 23\%; IUC cut, price war hurts. Retrieved from https:// economictimes.indiatimes.com: https://economictimes.indiatimes. com/markets/stocks/earnings/vodafone-india-q3-revenue-drops23-iuc-cut-price-war-hurts/articleshow/62744762.cms (accessed on 05 19, 2018)/

69. Seo, D. B., \& Ranganathan, C. (2009). Two-Level Model of Customer retention in the US Mobile Telecommunications Service Market.

Telecommunications Policy, 32, 182-196.

70. Sharma, V., \& Panga, M. D. (2018). Determinants of Switching Behaviour in Consumer Electronic Goods. Prestige International Journal of Management and Research, 10(4), 107-116.

71. Sharma, V., \& Sonwalkar, J. (2016) Consumer retention strategies for telecom service industry in India: a theoretical perspective. Journal of Management Research and Analysis, 3(3), 110-121.

72. Sharma, V., Kapse, M., \& Sonwalkar, J. (2016). Predicting the Switching Intention of CellPhone Brands: Application of Markov Chain Models. The IUP Journal of Marketing Management: 0972-6845, XV(4)

73. Sharma, V., Poulose, J., Mohanta, S., \& Antony, L. E. (2018). Influence of the Dimensions of CSR Activities on Consumer Purchase Intention. Innovative Marketing, 14(1), 23-32. http://dx.doi.org/10.21511/ im.14(1).2018.03

74. Sheth, J. N., \& Parvatiyar, A. (1995). Relationship Marketing in Consumer Markets: Antecedents and Consequences. Journal of the Academy of Marketing Science, 23(Fall).

75. Shukla, P. (2004). Effect of Product Usage, Satisfaction and Involvement on Brand Switching Behaviour. Asia Pacific Journal of Marketing and Logistics, 16(4), 82-104.

76. Siddiqi, K. O. (2011). Interrelations between service quality attributes, customer satisfaction and customer loyalty.
International Journal of Business and Management, 6(3)

77. Sweeney, J. C., \& Soutar, G. N. (2001). Consumer Perceived Value: The Development of a Multiple Item Scale. Journal of Retailing, 77(2), 203-220.

78. Szymanski, D. M., \& Henard, D. H. (2001). Customer Satisfaction: A Meta-Analysis of the Empirical Evidence. Journal of the Academy of Marketing Science, 29(1), 16-35.

79. TRAI (2017). Highlights of Telecom Subscription Data as on 21st November, 2017. New Delhi: telecom regulatory authority of India.

80. Vazquez-Carrasco, R., \& Foxall, G. R. (2006). Positive Vs. Negative Switching Barriers: The Influence of Service Consumers' Need for Variety. Journal of Consumer Behaviour, 5(4), 367-379.

81. Watson, F. G., Beck, T. J., Henderson, M. C., \& Robert, P. W. (2015). Building, measuring, and profiting from customer loyalty. Academy of Marketing Sciences.

82. Yanamandram, V., \& White, L. (2009). Are inertia and calculative commitment distinct constructs? An indirect test in the financial services sector. In D. Tojib (Ed.), Australia and New Zealand Marketing Academy Conference (ANZMAC) (pp. 1-9). Melbourne: Australian \& New Zealand Marketing Academy (ANZMAC).

83. Zablah, A. R., Bellenger, D. N., \& Johnston, W. J. (2004). An Evaluation of Divergent Perspectives on Customer Relationship Management: toward a common understanding of an emerging phenomenon. Industrial Marketing Management, 33, 475489.

84. Zikmund, W. G. (2004). Business Research Methods (7th ed.). Singapure: Thomson Asia Pvt. Ltd. 